\title{
The Concept of Mind in Hindu Tantrism
}

\begin{abstract}
This paper presents an account of the mind as found in pre-philosophical and philosophical Śaiva and Śaiva-Śākta literature and examines some important terms that the English word translates, notably, citta, cit, and manas, although there are others, mostly in the medieval or post-Gupta period. Through such inquiry we see an ambivalent attitude towards the category mind, on the one hand being a cause of bondage while on the other being elevated to the highest ontological category. Such an examination raises interesting historical questions about influences on the Śaiva and Śaiva-Śākta material and interesting philosophical questions about the category mind in relation to the category of the person.
\end{abstract}


It is well over sixty years since Herbert Guenther published his famous article on the concept of mind in Buddhist Tantrism, for which he used exclusively Tibetan sources. Guenther articulates the problem of translation and what we mean by 'mind' and 'mental' as translations of Sanskrit citta and caitta and the Tibetan sems and sems las-byun-ba. ${ }^{1}$ This current article is not so much an attempt to emulate Guenther's masterful study, although like him I do present an analysis of sources, but to present an account of mind as found in prephilosophical and philosophical Śaiva and Śaiva-Śākta literature. Of course, such a procedure is not ahistorical and although I may refer backwards to earlier sources, my focus will be on the post-Gupta or early medieval period. I will firstly proceed through an examination of key terms in selected tantric texts of what I have called elsewhere a pre-philosophical level of discourse ${ }^{2}$ then go on to use examples from philosophical texts within the Śaiva-Śākta milieu. Through such inquiry we see an ambivalent attitude towards the category mind - that translates a number of Sanskrit terms as we shall see - on the one hand being a cause of bondage while on the other being elevated to the highest ontological category. Although beyond the scope of the current paper to demonstrate thoroughly, we see different historical trajectories flowing in to the Śaiva traditions, namely a classical Yoga tradition, the Sāṃkhya hierarchy of ontic levels, and a view of the mind as all-pervasive. The yogic model of the mind as unstable is shared across traditions, while different understandings occur in philosophical discourse. Along the way, I will make reference to related traditions of Yoga and Buddhism and conclude with a historical reflection and a philosophical reflection on the category of mind in relation to

\footnotetext{
${ }^{1}$ Herbert V. Guenther, 'The Concept of Mind in Buddhist Tantrism,' Journal of Oriental Studies Hong Kong, vol. 3, July 1956, pp. 261-77. Allowing for the somewhat outmoded adjective 'Eastern', Guenther perceptively writes: 'If it is already difficult to know what we mean by these terms "mind" and "mental" in our own language, it will be readily admitted that it is still more difficult to ascertain the meaning of what is translated by "mind" or "mental" from Eastern texts. The question of whether the authors of the original texts actually meant the same as we do by those words about whose meaning we ourselves are not quite clear, should always be present, no only when translating texts but still more when dealing with a systematic presentation of Eastern philosophies' ( $\mathrm{p}$. 262). He later turned his article into a book, but the article remains a succinct summary.

${ }^{2}$ Gavin Flood, 'Implicit Anthropologies in Pre-Philosophical Śaivism,' Journal of Indian Philosophy, vol. 48 (4), 2020, pp. 675-701.
} 
those of self and person. An unthematized sub-text is that philological and textual work is a precondition for higher level historical and philosophical consideration.

The English word 'mind' (with its implicit distinction from 'body'), along with the term 'consciousness,' is used to translate a number of Sanskrit expressions, namely cit, citta, cetas, caitanya and manas and, in mostly Śaiva and Śākta sources, samvvit. There are also the words vijñāna and even jũāna that is often translated as 'cognition' rather than 'knowledge' in philosophy. ${ }^{3}$ Related to the concept of 'mind' are other categories implied by the word, such as memory (smaranam), whose semantic range is wider than the English term to include awareness, and appearance ( $\bar{a} b h \bar{a} s a h)$, the objects of consciousness. Citta, and associated terms such as manas, vijñāna/ viñ̃̃ana, have been used extensively in early Buddhist discourse - in the Abhidhamma of the Pāli Canon ${ }^{4}$ and in later Abhidharma of the Mahāyāna ${ }^{5}$ - as well as in Yoga, where Patañjali presents a Buddhist inspired analysis of mind. ${ }^{6}$ Through examining early texts we can build up a picture of the general concept and its place within the overall eschatological expectation of Śaiva Tantrism.

\section{The Concept of Mind in Pre-Philosophical Śaivism}

Guenther's view of mind within Tibetan sources is that that it has an 'inherent tendency to assume its 'natural' state when left alone', a view reflected to some extent in yogic texts such as the Amanaska that advocate the idea of no-mind and mindless yoga. ${ }^{7}$ In Saiva sources,

\footnotetext{
${ }^{3}$ E.g. Alex Watson, The Self's Awareness of Itself: Bhatta Rāmakantha's Arguments Against the Buddhist Doctrine of No-Self (Vienna: Institut für Südasien-, Tibet- und Buddhismuskunde der Universität Wien, 2006), p. 258.

${ }^{4}$ R.M.L. Gethin, The Buddhist Path to Awakening (Oxford: One World, 2001 [1992]), pp. 312-21; K.N. Jayatilleke, Early Buddhist Theory of Knowledge (London: George Allen and Unwin, 1963), pp. 434-38.

${ }^{5}$ Herbert V. Guenther, Philosophy and Psychology in the Abhidharma (Delhi: Motilal, 1974), pp. 4-94.

${ }^{6}$ On the influence of Buddhism on the Yoga-sütras see Lance Cousins, 'Vitakka/Vitarka and Vicāra: The Stages of Samādhi in Buddhism and Yoga,' Indo-Iranian Journal, vol. 35, nos. 2 and 3, (1992), pp. 137-55; Eli Franco, 'Introduction' p. 8, in Eli Franco (ed.) in collaboration with Dagmar Eigner, Yogic Perception, Meditation, and Altered States of Consciousness (Vienna: Verlag der Österreichischen Akademie der Wissenschaften, 2009), pp. $1-54$.

${ }^{7}$ Jason Birch, The Amanaska: king of all yogas: a critical edition and annotated translation with a monographic introduction, DPhil., University of Oxford, 2013.
} 
however, the picture is more complex, with the category of 'mind' - as a translation of citta and also manas - being individually unstable and the product of a cosmological process which explains human experience in the world, as well as accounting for the withdrawal of the mind from the world back to its origin in a transcendent reality. The sections on yoga in the Saiva Siddhānta Tantras follow the general orientation set by the yoga system of Patañjali, who the Śaiva commentators quote, although there are other traditions influencing them, namely the cosmological hierarchy of Sāṃkhya and an earlier Yoga tradition discussed by Vasudeva that emphasized the mind as pervasive. ${ }^{8}$ The mind is uncontrolled and undisciplined, driven by desire, which leads to suffering and rebirth, yet the controlled mind leads to transformation, to magical accomplishment (siddhiḥ) and liberation (mokṣaḥ).

i) Controlling the uncontrolled mind

On the one hand the mind, as a rendering of both citta and manas, is negatively evaluated because of its nature to wander from one object of consciousness to the next, which needs to be controlled in order to raise up the self in a verticality towards transcendence. This is the standard yogic model of the mind found in Patañjali's Yoga-sütras 1.2 where he defines yoga as 'the cessation of mental fluctuation' (yogaś cittavrttinirodhah). ${ }^{9}$ In this gnostic model, through mental control, the self is freed from the mind's clutches and can go beyond the body, although using the body as the means to achieve this end. The model is almost certainly influenced by Buddhism and the Buddhist understanding of mind (see note 6) and influenced the Śaiva Siddhānta scriptures in which yoga comprises 'limbs' (aingāni), although often six

\footnotetext{
${ }^{8}$ Somadeva Vasudeva, The Yoga of the Mãlinīvijayottaratantra (Pondichéry: Institut Français, 2004), p. 430.

${ }^{9}$ Hariharananda Aranya, Yoga Philosophy of Patañjali: containing his yoga aphorisms with commentary of Vyāsa in Sanskrit, and annotations thereon with copious hints on the practice of yoga (Calcutta: University of Calcutta, 1977), 1.2 .
} 
rather than eight. An example of this yogic understanding is found in the Yogapāda section of the Mrgendrāgama. ${ }^{10}$ The text begins with a curious statement:

Now, having thought that it is very difficult for those who do not possess a self to have their own mastery, the teachers and others, desiring to win, make an effort to possess the self. ${ }^{11}$

The commentary of the Śaiva Siddhānta theologian Bhaț̣a Nārāyaṇakaṇṭha ${ }^{12}$ tells us that those who possess the self are those for whom the self is known (ātma vidyate). He goes on to ask, 'but what is this 'possession of the self?' (ätmavatvam)?' The text answers:

A possessor of self is the condition of being a Yogin. It is produced for someone who has controlled his senses, performing breath control and so on; very gradually the senses are controlled. ${ }^{13}$

This gradual achievement is through the process of breath control, contraction of the senses, fixing or focusing the mind, meditation, examination, repetition of mantra, concentration, and the eighth stage is yoga itself. ${ }^{14}$ And because of this process, the controlled mind is free to settle on whatever the Yogin desires:

\footnotetext{
${ }^{10}$ This, along with the Matangaparameśvara, is a scripture of the Śaiva Siddhānta, a branch of Mantra Mārga Śaivism, whose scriptures can mostly be dated between the ninth and twelfth centuries, although part of the Niśvāsa corpus goes back to the fifth. See Alexis Sanderson, 'Śaiva Literature,' Journal of Indological Studies, nos. 24 \& 25 (2012-2013), pp. 5-8. The Mrgendra was commented on by the theologian Bhatta Nārāyanakantha who lived in the second half of the tenth century and the Matanga by his son Bhațta Rāmakanțha (Sanderson, 'Śaiva Literature,' pp. 15-16).

${ }^{11}$ Mrgendrāgama Yogapāda, 1: athānātmavatām matvā / svādhikāram suduṣkaram / yaterannātmavanto ye / deśikādya jigịsavah. This idea is echoed in the Netra-tantra (1.23) where the text refers to 'unmade souls' (akrtätmāh), perhaps referring to unrestrained souls. Perhaps this is also the sense here.

${ }^{12}$ Bhaț̣a Nārāyanakanțha and his son Bhața Rāmakaṇțha were active during the second half of the tenth century. Sanderson, 'Śaiva Literature,' pp. 16-17.

${ }^{13}$ Mrgendrāgama Yogapāda, 2: tadātmavatvam yogitvam jitākșasyopapadyate |prānāyāmāädyanușthānājjitākșatvam śanaiśśanaih. (Unless otherwise stated, all translations are my own. After completing this, I discovered that Alexis Sanderson has an unpublished translation of the Yogapāda, but at the time of writing this I have no access to it.)

${ }^{14}$ Ibid. 3: prānāyāmah pratyāhāro dhāraṇa dhyānavīkṣane | japas samādhir ityañgānyainḡ̄ yogo 'ștamas svayam.
} 
Through this, the intention of consciousness to turn back from contact with the objects of the senses [means that the mind] is suitable for focusing on a condition produced by one's own will. ${ }^{15}$

Bhaț̣a Nārāyaṇakaṇțha explains that through the discipline of the breath, thought (matihn) is cut off from contact with sense objects and this allows it to settle on any object it chooses. He explains:

With the withdrawal of the mind (cit) from contact with the objects of the senses, by the mind (citta-), [consciousness is] cut off. This cessation (virati-) of its own usual occupation (svavyāya-) is the reason why the mind goes towards something [higher] that can be focused upon, in a condition according to its own will, as about to be described. The mind (matih) here does not [mean] the intellect (buddhih) but the usual activity of the mind (cetaso vyāpārah) which is called bringing together of thought (matissankalpa-), which is thinking (mananam). This is due to the support of its being focused. So, Patañjali says: 'the focusing of the mind (citta-) is the strength of the body,' 'thus the mind (mana-) becomes adapted to its focuses.' 16

Through the discipline of Yoga, the mind becomes detached from the objects of the senses and because of this withdrawal, it achieves a freedom to settle, to become fixed according to the Yogin's will. I rendered the expression mati as 'thought' and 'intention' although it could designate mind more generally and so be a synonym for manas. Thought adapting to its focus is saying that the mind takes the form of its objects. Once detached from sense objects, Bhatța Nārāyanakaṇtha is saying, the mind can go to whatever the Yogin desires, perhaps with the

\footnotetext{
${ }^{15}$ Ibid. 6: tenendriyārthasamsargavinivṛtteś cito matih |dhāraṇāyogyatāmeti pade svecchāprakalpite.

${ }^{16}$ Ibid. com: tena pratyāhārena citaś cittasyendriyārthasamyogāt pratyāhṛtatvādyā vinivrttih svavyāpāraviratistasyā hetubhūtāyāḥ svecchāprakalpite pade vakșamānadhārañāyogyatām matir abhyeti | nacātra matirbuddhih api tu mananạ̣ matissan்kalpākhyaścetaso vyāpārạ̣ tasyaiva dhāraṇāśravaṇāt | yadāha patañjaliḥ dehabalaś cittasya dhāraṇā iti | tathā dhāraṇāsu manasoyogyateti.
} 
connotation of going to whatever world he desires. Iccha has the double connotation of both 'will' and 'desire' as the driver of what objects (or worlds) the mind settles upon. ${ }^{17}$

Bhaț̣a Nārāyaṇakaṇțha goes on to define the remaining eight 'limbs' (aingāni) of Yoga, although they are different to those of Patañjali (Yogasūtra 2.29) whom he cites with approval, so after defining breath control, contraction of the senses, focusing the mind, he goes on to meditation, examination, repetition of mantra, and concentration. There is no restraint (yamah) or control (niyamah) and examination (vīkṣaṇam) and repetition (japah) are added with yoga being a summative eighth. ${ }^{18}$ So, in the text, meditation (dhyānam) is defined as thought (cintā) fixed on a particular object (tadvișayā). And here Bhațta Nārāyaṇakaṇțha brings out the distinctly Tantric meaning of dhyāna as visualization, for he describes it as identification with the object of meditation, or more literally, meditation is when the mind (cittam) is overspread with its focus (dhâraṇāruddham), which we can take to mean comes to be absorbed in its objects. More specifically, at this level, the specific focus refers to Siva with three eyes, five faces, and so on, each face having a particular colour. So, he explicitly links meditation to visualizing Śiva in the form of the five faced Sadāśiva, the central deity of the Śaiva Siddhānta. The basic idea is clear, that through the forced control of the breath, the mind (manah) can be controlled because there is a link between mind and breath: 'the reason for the repression of the mind is because of its contact with breath and affliction' (nivrtter manaso hetuh samsargāt prānakhedanam). ${ }^{19}$ Once the mind is calmed, then higher levels of awareness that are higher levels of the cosmos, can be entered into: 'whenever [the Yogin] calms the mind (cittam) in

\footnotetext{
${ }^{17}$ In the Śaiva context of the methods (upāya hh) to attain liberation, Sanderson captures the sense of the concept $i c c h \bar{a}$ in translating it as 'pre-cognitive impulse,' Alexis Sanderson, 'Manduala and Āgamic Identity in the Trika of Kashmir,' p. 170, in A. Padoux (ed.), Mantras et diagrammes rituels dans l'hindouisme (Paris: CNRS, 1986), pp. 169-214.

${ }^{18}$ Different tantras have varying lists. The Suprabhedāgama (Yogapāda 3.54-55) gives the same list at Patañjali but inverts dhāranāa and dhyāna. The Kirana-tantra (Yogapāda 3) presents six limbs and the Raurava (Vidyāpāda 7.5) enumerates six as well, namely pratyahāra, dhyāna, prānayāma, dhārana, āsana, samādhi (see the discussion N.R. Bhatt, 'introduction,' pp. xxv-xxvi, Matangaparameśvara-tantra (Kriyāpāda, Yogapāda, et Caryāpāda) avec le commentaire de Bhațta Rämakanțha (Pondichéry: Institut Français d'Indologie, 1982), pp. v-lxxviii.

${ }^{19}$ Ibid. 12ab.
} 
the body of becoming, or in the body of being, there progress (bhīyobhūyah) can be meditated upon through being united in concentration to the teachings of the master. ${ }^{20}$ The two bodies referred to, probably mean the subtle and gross bodies respectively, the vehicles of the soul's journey. A new word here has been introduced: $\operatorname{cint} \bar{a}$, 'thought' which Vasudeva takes to mean the flow of thoughts as the object of consciousness, ${ }^{21}$ in other words, intentional objects. The term manas is thus used in two senses, to mean the restricted awareness of the bound person as well as more specifically the category (tattvam) of the sense that perceives inner objects or thoughts. In a Nyāya context, that can also apply to the Śaiva Siddhānta, Chakrabarti translates manas as 'inner sense.'22 Thus the manas is the function or even organ or perception that perceives the flow of intentional objects ( $\operatorname{cint} t \bar{a} h)$.

The same idea is found in other Śaiva Siddhānta texts such as the Matangaparameśvara, where meditation (dhyānam) is strong attachment to the object of meditation, and this is determined by the power of the object, followed by breath control in which breath (prānah $)$ becomes united to consciousness. Posture (āsanam) is complete immobility of the body during breath control, followed by one-pointed concentration (ekägratah), then examination (tarkah) which discriminates different ontic levels (tattvāni) as the mind (manah) rises to the highest, the siva-tattva. As in other Tantras, meditation is placed before focusing (dhāraṇa $)$, thereby emphasizing the stability of the mind in one-pointed concentration. ${ }^{23}$ Withdrawal (pratyahārah) is the beginning of stabilizing the mind and stopping it from wandering. The text begins its description of the limbs of yoga in a somewhat enigmatic and obscure way. Śiva is speaking:

\footnotetext{
${ }^{20}$ Mrgendrāga, Yogapāda 59, comm: yatra yatra bhāvaśarīre bhütaśarīre vā cittam upaśāmyati tatra tatra bhūyobhūyah prayatnavatā gurūpadeśasamadhigatayuktinā dhyātavyam.

${ }^{21}$ Vasudeva, The Yoga of the Mãlinivijayottaratantra, pp. 428-32.

${ }^{22}$ Kisor Kumar Chakrabarti, Classical Indian Philosophy of Mind: The Nyāya Dualist Tradition (Delhi: MLBD, 1999), p. 104.

${ }^{23}$ Bhatt, 'Introduction,' Matangaparameśara, p. xxvii.
} 
Now I will name concisely the extensive limbs of the immeasurable splendour of yoga. Listen, O Sage, with your own mind focused.

2.1. [We suffer] due to the usual operation (niyogatah) of senses turning around in their own [spheres or objects] such as sound and so on, with desire [for them] because of the agitating force from [the place of] one's own abiding.

2.2. Having pulled together the afflicted [senses] each by its own path, this is the success of [mental] behaviour contrary [to the usual working of the mind], after entering the belly of the lotus.

2.4. [The uncontrolled mind] is a stone worn down and tossed about [but pierced] by the needle of knowledge, strung with the thread of the mind, held by the hand of thinking.

2.5-6ab. This is the rosary to be counted, for the one embodied in the refuge of the lotus of the heart, having drawn together the moving mind for the sake of the refuge of the heart, by which it will be properly sheltered. This is called withdrawal.

2.6cd-7. From procuring [this meditational] nourishment, pure joy arises. There is satisfaction in sweeping together the objects [of the senses], but also with obtaining unimpaired [focus], then having brought together [consciousness] due to the cessation [of the moving mind], that is called withdrawal. ${ }^{24}$

So, withdrawal is the cessation of the movement of the mind and abiding in the heart. There is no commentary by Bhatța Rāmakaṇtha on this section of the text and there are difficulties regarding the precise meaning of some terms. I have taken svādhișthätṛaleraṇât to mean

\footnotetext{
${ }^{24}$ Matañgaparameśvara-tantra. Yogapāda 2.1-7, pp. 251-52: athāngāni variș̣thāni yogasyāmitatejasah / samāsato'bhidhāsyāmi śrṇuṣvaikamanā mune // 2.1// sveșu sveșu pravrttānām indriyānām niyogatah / śabdādișv abhilāṣena svādhișthātrtrbaleraṇāt //2.2// nișanṇānām samākrș̣ya svena svena tu vartmanā / pratīpācārasiddhis tu praveśya kamalodare //2.3// jñānasūcisamāviddhanighrșțārthopalā purā / manahsūtreña samprotā matihastasamāśsitā //2.4// prasaṃhyeyākșamāleyam hṛtpadmāśrayamūrtinah / cittam pratisamāhṛtya calitam hrdayāśrayāt //2.5// samyaksamāśrayo yena pratyāhārah sa ucyate / āhārāt poșanam prītih prasādah samprajāyate //2.6// saṃtoșo'rthasamūhe tu pratipattyāpy akhanditah / tadā hrtya nirodhāc ca pratyāhārah sa ucyate $/ / 2.7 / /$
} 
'because of the agitating force (ìrana-) from [the place of] one's own abiding' but ìrana could refer to 'wind,' in which case one might speculate that the phrase refers to a 'wind' or breath in the body that rises upwards from the 'own place' as the lowest circle in the body's esoteric anatomy, although this somatic system of hierarchical levels or centres in the body had not yet developed at the time of the Matanga's composition and we should be cautious about reading later meanings back into the earlier texts. But the sense seems to be that the wandering mind, settling on the different objects of the senses, is itself driven by somatic forces. This kind of model would be in consonance with other texts such as the Netra-tantra where, in chapter seven, a structure of the body is presented with various centres located along a central axis with a network of channels pervading the body through which the breath or subtle power flows. ${ }^{25}$ The term kamalodaram might similarly refer to such esoteric anatomy of a subtle body, perhaps another term for the svādhișthāta mentioned in the passage, that was to become famous in later yoga traditions. So, the sense is that the Yogin's concentration is focused on this centre in the body at or below the stomach and that this concentration turns the mind away from the usual occupation of the mind in the sense spheres. The bodily image then shifts to the heart, where the image of the self abides, concentrating on which the wandering mind is contained. The mind is controlled by the Yogin concentrating on this who then achieves withdrawal from the sense spheres.

With the withdrawal of the mind from the sense spheres, the Matanga offers an account of the ascent of the soul through the levels of the cosmos within the body, from the earth to nature (prakrtih) (chapter four) and then the conquest of the puruṣa-tattva upwards (chapter five). Once in the pure realm, souls can attain seven kinds of liberation (prakärah) in a hierarchical order. ${ }^{26}$ Here the text presents correspondences between ontic levels (tattvāni) and

\footnotetext{
${ }^{25}$ Netra tantra chapter 7.1-5.

${ }^{26}$ Mrgendrāgama, Yogapāda 5.63-69.
} 
levels of liberation. This section of the text does not refer to 'mind' which has been left behind in the lower creation.

The same idea is found in non-Saiddhāntika scriptures too, such as the Mālinīvijayottara-tantra, for Abhinavagupta the foundational scripture of the Trika religion. ${ }^{27}$ Like the Mataiga, it presents a journey through the ontic levels of the cosmos that the Yogin needs to follow: 'The Lord of yoga should master all [of the realities] beginning with earth up to Śakti with a view to the destination (lakșa), or in accordance with his disposition (citta). ${ }^{28}$ The term cittabheda, Vasudeva informs us, means 'in accordance with one's disposition' and refers to the Yogin's motivation for his journey. So, the variety of dispositions might correspond to the variety of goals because different targets are different manifestations of Śiva and approaches to him. ${ }^{29}$ In the Mālinī there are six such goals that the Yogin may approach, each bringing its own reward. ${ }^{30}$ Here citta designates a motivating force and individual character, although there are places in the text where it is used in the senses we have examined, as a fluctuating distraction that needs to be repressed. The Mālinī also contains the idea of limbs or ancillaries of yoga, only here there are six. ${ }^{31}$

\section{ii) Mind in Cosmology}

The human mind in this worldview is set within a cosmological context and is the result of massive forces controlling the particularity of mind into what it is. There are a number of terms we need to look at, in particular citta, which is all pervasive in tantric texts in varying degrees and we need to pay attention to the cosmological process that controls consciousness

\footnotetext{
${ }^{27}$ Vasudeva, The Yoga of the Mālinivijayottara, p. xxxix.

${ }^{28}$ Ibid, p. 253 citing the Mālinī 12.8-9.

${ }^{29}$ Ibid. p. 255.

${ }^{30}$ Ibid, p. 256 citing Mālinī 12.9: 'The category of the aim (laksya) is considered to be six-fold according to the division of [1.] void (vyoman), [2.] body (vigraha), [3.] drop (bindu), [4] phoneme (arna), [5.] world (bhuvana) and [6.] resonance (dhvani)...'

31 Vasudeva, The Yoga of the Mālinīvijayottara, pp. 367-82, prāṇayāma, dhāraṇa, tarka, dhyāna, samādhi, and pratyahāra.
} 
into its particularity. We need to locate the idea of the mind within the broader conception of person and world, which is to place the mind in the context of the hierarchical cosmology. Details of this cosmology can be found elsewhere, ${ }^{32}$ but briefly the worldview of the Śaiva tantras is that the hierarchical universe emanates from a subtle source (referred to as the 'drop', bindu, the subtle material substrate). The pure cosmos is the first emanation from Siva and Śakti comprising the ontic levels or tattvas associated with forms of Śiva, namely Sadāśiva, İśvara, and Śuddhavidyā, each combined with their power, Icchāśakti, Jñānaśakti and Kriyāśakti. The powers of Cit- and Ānanda are associated with Śiva- and Śakti-tattvas, the highest ontic categories concerning which there is an ambiguity, being both the first emanations and the source of emanation. Following the pure course, the impure cosmos is a more solidified emanation from the ontic category of $m \bar{a} y \bar{a}$, the substrate and substance of the lower universe, which in turn is reflected in an even lower manifestation of prakrti, material nature, from which emanates the, yet lower still, universe down to earth (prthivi) . This whole structure is conceptualized as thirty-six ontic levels or categories (tattvāni) made up of the standard twentyfive Sāṃkhya categories plus eleven Śaiva ones, woven together. The human mind is the consequence of these higher forces emerging from prakrti. Thus, the 'inner instrument' (antaḥkaraṇah) comprising intellect (buddhihh), ego (ahamkkārah̆) and 'mind' (manaḥ) covers much of what the English term 'mind' designates. Citta is not listed as one of the ontic categories, although individual conscious awareness is a consequence of this cosmological sequence.

In the process of the unfolding of the cosmos outlined in the Śaiva Siddhānta scripture, the Mrgendrāgama, the buddhi faces towards the self, which is pure consciousness, and

\footnotetext{
${ }^{32}$ E.g. Dominic Goodall, 'How the Tattvas of Tantric Śaivism Came to Be 36: the Evidence of the Niśvāsatattvasamhitā', in Dominic Goodall and Harunaga Isaacson (eds.), Tantric Studies: Fruits of a Franco-German Project on Early Tantra (Pondichéry: Institut Frañcais, 2016), pp. 77-112. André Padoux, Rescherches sur la Symbolique et l'Énergie de la Parole dans certains textes tantrique (Paris: de Boccard, 1963), pp. 261-86; Jagdish Chandra Chatterji, Kashmir Shaivism (Srinagar: Kashmir Series of Texts and Studies, 1914), pp. 64-147.
} 
towards material nature which is its immediate origin. It contains two structures, the fundamental predispositions $(b h \bar{a} v \bar{a} h)^{33}$ and the fundamental conceptions (pratyayāh), the latter emerging from the former which is its material cause (upādānah), ${ }^{34}$ and the bhāva-s themselves emerging from, and being caused by, the qualities or guna-s of prakrti, which pervade all the world. ${ }^{35}$ There are eight fundamental predispositions: towards virtue (dharma), knowledge (jñāna), dispassion (vairāgya), sovereignty/power (aiśvarya), and their opposites, non-virtue (adharma) and so on, which in turn give rise to the four fundamental conceptions of power (siddhi), contentment (tuști), non-power (aśakti), and error (viparyaya). The positive fundamental predispositions, virtue, knowledge, and so on, are governed by the quality of lightness (sattvam) whereas their opposites are governed by darkness (tamah). We might simplify or generalize this scheme to say that these predispositions innate within the mind predispose the person either towards higher knowledge and power or towards lower pleasure and obstacles to enlightenment. The chapter on the bhāva-s in the Mrgendra concludes:

[The innate dispositions] naturally result in a power over dominated beings and are linked to complete knowledge [of them]. [On the one hand they result in] lack of desire towards [worldly] pleasures, the withdrawal from the group of obstacles, [yet also on the other to] attachment to [worldly] pleasures, being humiliated, to the illumination of the body, obstacles, and objects. ${ }^{36}$

\footnotetext{
${ }^{33}$ I follow Larson's translation of bhāva, G.J. Larson and Ram Shankar Bhattacharya (eds), Encyclopedia of Indian Philosophies vol IV, Sāmkhya, a Dualist Tradition in Indian Philosophy (Delhi: MLBD, 1987), p. 53. Mrgendrāgama, Vidyāpāda, 10.24: bhāvā buddhigunā dharmajñānavairāgyabhütayah | sātvikà vyatyayenaite rägamutşyya tämasăh. 'The dispositions are the qualities of intelligence, virtue, knowledge, dispassion, power. They are light and their opposite, apart from passion, is darkness (tamas).'

${ }^{34}$ Mrgendrāgama, Vidyāpāda, 10.25. These categories are themselves curious. First occurring in the Sämkhya$k \bar{a} r \bar{k} k \bar{a} s$ of İśvarakṛsna, these lists seem to be an attempt to account for aspects of experience given positive and negative value. In his commentary Bhaț̣a Nārāyankanțha says that pratyāya-s, that I have called fundamental conceptions, make known the transmigrating soul: te dharmādaya upādānam utpattihetur yeșām te samsāryanoh pratyāyanāt pratyayā iștāh. 'Fundamental conceptions [are so called] because they make known the transmigrating soul of which they are the reason for its arising.' I have followed Hulin who renders pratyāyanāt 'font connaître' (Michel Hulin, Mrrgendrāgama, Sections de la Doctrine et du Yoga (Pondichéry: Institut Françasi, 1980), p. 241).

${ }^{35}$ Mrgendrāgama, Vidyāpāda, chapter 11

${ }^{36}$ Mrgendrāgama, Vidyāpāda, 10.30: vaśyākrāntis tat parijñānayogo bhogānicchā vighnasañghavyapāyah | bhogāsaktir nyakkrtir dehabuddhir vighnaś cārthās teșu sāṃsiddhikeșu.
} 
This is somewhat obscure, but I take it that the innate dispositions lead to power over others who become dominated beings ( $\left.v \bar{a} s y^{\prime} \bar{a}\right)$, on the one hand, and on the other they can be the cause of attachment, rebirth and being overcome by obstacles. Aghoraśiva's commentary helps illuminate the meaning of the passage to some extent, that complete knowledge of other beings occurs when one attains to the state in which others appear as objects of perception (tatparijñānayoga iti tadvișayajñannaprāptih) towards which there is lack of desire. From the innate disposition of attachment or specifically non-detachment (avairāgyāt) there arises the illumination of the body (dehabuddhih). The commentators do not remark on the use of buddhi but if we take this as a tatpuruṣa compound, we can perhaps take this to mean that a new body arises for the bound self because of attachment. Although the detailed meanings of such verses are often now obscure, the general analysis of mind is clear that within the buddhi there are two orientations, one towards power and success (power over others) and liberation - upwards in the Śaiva metaphor - the other towards worldly pleasures and so obstacles and embodiment in a new body. The mind (cittam) as consequence of this evolution is the instrument of perception within a person that is formed through complex cosmological structure of which the ordinary mind is mostly unaware.

The Mrgendra precisely follows the Sāmkhya system, even in its analysis of the pratyaya's into further categories. ${ }^{37}$ These dispositions and conceptions determine the quality of a living entity's experience and are both orientated towards liberation and towards material nature (prakrti). ${ }^{38}$ Similarly, the fundamental conceptions that determine the quality of embodiment, are themselves controlled by the qualities of material nature, the guna-s, so sattva becomes active in a person's ability to perceive the higher ontic levels and so attain liberation. ${ }^{39}$ A number of terminologically complex features are thus introduced to explain human

\footnotetext{
${ }^{37}$ Mrgendrāgama, Vidyāpāda, 10. 25 corresponds to Sämkhya-kārikās 12.43-52. Larson and Bhattacharya, Sāṃkhya, pp. 160-61.

${ }^{38}$ Mrgendrăgama, Vidyāpāda, $10.29 \mathrm{~cd}$.

${ }^{39}$ Mrgendrāgama, Vidyāpāda, 11. 2-3.
} 
experience and the mind's orientation towards the world and so entrapment in rebirth and the mind's orientation towards transcendence. This complexity is arguably because of the historical inheritance of the Sāṃkhya categories within the Śaiva system and also of ideas about citta from a yogic understanding of consciousness. The fundamental conceptions are drivers of mind in that they give rise to awareness or realization and the satisfied sense (tuștih) of having realized a goal or attained an action. ${ }^{40}$

The complex of function of the 'inner instrument' (antahkaranam) that maps onto the idea of mental functioning is the consequence of cosmological forces. It is the buddhi that contains the traces, the potentially active force remaining latent until brought to fruition, that result in future action and future experience. And so, these latent traces are, in a sense, memories of the past, although not at the level of awareness. Indeed, the buddhi itself is unconscious (jadah), illuminated only by the consciousness that is the self (puruṣa-/ pumstattvam). The person's interaction with the world through the group of senses and whole structure of the lower ontic levels - the five senses, the five faculties of action, the five subtle senses - are embodied in world through the gross body (sthülaśarīrah) that comprises the material elements, itself derived from the subtle body (sükșmaśarīrah) or 'city of eight' (puryāștakah) comprising the inner instrument plus the five subtle senses (tanmātrāni). ${ }^{41}$ Turning away from the world towards an inner transcendence, consciousness particularized through the apparatus of the inner instrument withdraws from interaction with the world and moves upwards, and inwards, towards Śiva. In the earliest Śaiva scripture that has come down

\footnotetext{
${ }^{40}$ Mrgendrāgama, Vidyāpāda, 11.2: pumprakrtyādivișayā buddhiryā siddhir atra sā |tuṣtir nur akṛtārthasya $k r t \bar{a} r t h o ' s m \bar{t} t i$ ya matih. 'Intellect whose object is the pure self and material nature etc., is called here understanding, contentment is the thought: 'I have reached my goal,' [but in fact] he has not reached his goal.' That is, the sense of satisfaction arises even though the goal has not, in reality, been reached.

${ }^{41}$ For this overall structure being constitutive of ancient Indian view of person see Jessica Frazier, Hindu Worldviews: Theories of Self, Ritual and Reality (London: Bloomsbury, 2017), pp. 41-47.
} 
to us, the Nihsśvāsatattvasamhitā we read how the disciple of Śiva should meditate, concentrating his mind within himself:

4.17c-18b: He should concentrate his thoughts/mind in his head and fix his eyes [to look] upwards. [While he is] practicing thus, the door into the fourth state is broken through.

4.18c-19: There arises [for him] there a sensation/awareness/sign (pratyayam) comparable to the touch of wind. Or like [the crawling of] an ant [upon him], or like being pricked by a thorn. Smokeless burning fire flames in his body.

4.20: A divine smell will arise, and a divine voice begin [to speak]. He knows whatever he thinks about, even [in the realm of] unknown Śāstras.

4.21: He becomes radiant, full of beauty, ascending [into the air] he moves about. After three months, conversation with Siddhas comes about [in his experience].

4.22-3: He sees [all creatures] from Brahmā down to blades of grass with divine vision; within a year he sees a crescent moon above [his own] head. Above that [crescent moon?] he sees Śiva at peace and becomes immortal, omniscient, able to change form at will and becomes equal to Śiva. ${ }^{42}$

Here we see a focus on inner, contemplative experience and the idea of mind (cittam) as something that can be used to focus his concentration. Through the practice of fixing the citta within, the practitioner breaks through the 'door' into the fourth state, the state beyond waking, dreaming and sleeping. Through this elevation he experiences transactions with supernatural beings, otherwise invisible, and eventually becomes equal to Śiva (śivatulyah),

\footnotetext{
${ }^{42}$ Niḥśvāsatattvasaṃhitā, Nayasūtra 4.17c-23: mūrdhni cittam samālambya ūrdhvañkṛtvā tu cakșuși //4.17// evam abhyasamānas tu turyadvāram vibhidyate /pratyayañjāyate tatra vāyusparśasamopamah //4.18// pipīlikāsamo vāpi kanțakā[vedha] \{sa\} [pra]bhah /agnir jvalati dehe tu adhümo dahanātmakah //4.19// divyagandhaś ca jāyeta divyavāṇ̄ pravarttate lapūrvaśästram yatkiñcintitam tu vijānate //4.20// tejasvī kāntiyuktaś ca ürdhvagāmī tu mañcaret /siddaiś ca saha sambhāssyam tribhirmmāsaih //4/21//ābrahmastambaparyantạn paśyate divyacakșu[șā]/[samca]tsarenārdhacandram paśyate ca śiropari //4.22//tatopari śivam śāntantandrșțāa cāmrtī̄bhavet /sarvajñah kāmrūpī ca śivatulyaś ca jāyate //4.23// (Goodall's translation.)
} 
the idea of liberation in this tradition. In these passages the mind is a force that rise upwards, through the inner door into the higher state and the cognition of God. Here we see citta as the process of being aware, which is turned inwards through a technology of meditation and ritual in the belief that liberation and/or pleasure in higher worlds can be a consequence. An eschatological hope drives the practices that turn the mind away from the world.

This basic model is found not only in the scriptures of the Saiva Siddhānta but in the non-Saiddhāntika corpus of scriptures as well. In a reinterpretation of the eight limbs classical yoga, the Netra-tantra describes a similar process of the Yogin turning the mind inwards.

8.12-13ab. Having abandoned the gross condition of the breath and so on, [the Yogin should] similarly [abandon] the subtle, inner path; after that he will attain the supreme vibration beyond the subtle. This is called breath control (Prānayāma) from which the mind does not move.

$8.13 \mathrm{~cd}-14$. The fluctuations of the qualities beginning with sound are experienced by the mind, abandoning which, [the Yogin] may enter the supreme place by his own mind. This is called 'withdrawal' (Pratyahāra), cutting the noose of becoming.

8.15. Having gone beyond the intellect, the qualities, [and] the mind, meditating on the unchanging Lord without qualities, who is the object of meditation and reflexive awareness, the wise know this to be 'meditation' (Dhyāna).

8.16. The supreme self is held by the 'supporting concentration' (Dhāraṇa) at all times. That 'supporting concentration' (Dhārana) is defined [here as] the destruction of the bond of becoming.

8.17. The placing of consciousness equally in all beings is called 'absorption' (Samādhi). [This is the real meaning] otherwise people are befuddled. ${ }^{43}$

\footnotetext{
${ }^{43}$ Netra-tantra 8. 12-17 (Na f.19r) : prāṇādisthūlabhāvam tu tyaktvā sūkṣmam pathāntaram / sūkṣmātītam tu paramam spandanam labhyate yatặ // 12 // prāṇāyāma[h] samuddiṣto yasmān na cyavate manaḥ / śabdādigunavṛttir yā cetasā hy anubhūyate // 13 // tyaktvā tām paramam dhāma praviśset tat svacetasā / pratyāhāram iti proktam bhavapāśanikṇtanam // 14 // dhīr gunān samatim kramya nirgunam cāvyayam vibhum / dhyātvā
} 
Consciousness that arises from breath control is a means of going beyond its limitation to a higher state of absorption (samādhih) and realizing that consciousness that is placed in all beings is the same. Elsewhere in the text this process moves upwards through levels of sound to a condition 'beyond the mind' (unmanā), a condition that has transcended the lower levels of manifestation. In the NT's account, this sound cosmology is divided into twelve parts $($ kalā $)$ of which eleven are perishable and the twelfth is imperishable as Siva's power (śaktih). These levels are in order: A, U, M, bindu, ardhacandra, nirodhī, nāda, nādānta, kaundalī, vyāpinīi, and saman $\bar{a}$, which also correspond to the ontic levels. The eleventh is unman $\bar{a}$, transcendence, the 'beyond mind,' identified with Śiva and Śakti. ${ }^{44}$ The text states:

[The sound sequence is] the syllables A, U, M and then the drop, the half-moon, cessation, the sound, and the end of the sound, then the circular one, the all-pervading power, and [the level] with mind. [These are to be] pacified. Then the partless ontic level of the self, then power which is beyond mind. This [level] has brilliance [then follows] the supreme, highest ontic level without brilliance [i.e. Śiva]. ${ }^{45}$

The first eleven levels culminate in samana , 'with mind,' while the transcendent level is unmana $\bar{a}$, 'beyond mind' with the ontic category of the self (ätmatattvam) being between the two. Here the term manas refers not to the ontic category that comprises one of the components

\footnotetext{
dhyeyam svasaṃvedyam dhyānam tac ca vidur budhāh // 15 // dhāraṇā paramātmānam dhāryate yena sarvadā / dhāraṇa sā vinirdiștā bhavabandhavināsinin // 16 // samas sarveșu bhüteșu àdhānam cittavigraham / samādhānam iti proktam anyathā lokadāmbhikam // 17 //. 8.12b pathāntaram] Na: athāntaram K; 8.13b manah] Na: punah K; 14a paramam] $\mathrm{Na}$ : praviśed $\mathrm{K}$; $14 \mathrm{~b}$ praviśet] Na: paramam $\mathrm{K}$; 14c pratyāhāram iti proktam] Na: pratāhāra iti prokto K; 14d bhavapāśanikrntanam] Na: bhavpāśanikṛtakaḥ K; $15 \mathrm{~b}$ nirgunaṃ] Na: nirdhyeyam K; $16 \mathrm{a}$ paramātmānaṃ] Na: paramātmatvam K; 17a samas] Na: samam K; 17b ādhānam cittavigraham] Na: àdhāram cittanigrahah $\mathrm{K}$.

${ }^{44}$ For correspondences between this structure and other cosmological structures, levels of speech, energies, ontic levels and so on, see the diagram in Padoux, Recherches, p. 347.

${ }^{45}$ Netra-tantra 24.21-23 (f.85 r) = K 22.21-23: akāraś ca ukāraś ca makāro bindur eva ca |ardhacandro nirodhī ca nādo nādānta eva ca //24.21// kauṇ̣̂alī vyāpi[nì śaktih samanāś] ...tastu sāmayā[h] / niṣkalam cātmatattvam tu śaktiś caiva tathonmanā //24.22// sābhāsam tam ṇirābhāsam / paratattvam anuttamam //24.23//. 24.22b ...tastu] Na: ceti K; 24.22c tu] Na: ca K; 24.23a tam] Na: tat K. Translation follows K as Na damaged at edges. The Netra-tantra adds kauṇ̣̂ali and according to Kșemarāja's commentary on K, qualifies śakti as vyāpinī, making eleven before unmanā. The sequence in other texts such as the Somaśambhupaddhati is that after AUM we have bindu, ardhacandra, nirodhin̄̄, nāda, nādanta, śakti, vyāpin̄̄, samanā and unmanā (Hélène BrunnerLachaux, Somaśambhupaddahti vol. 3 (Pondichéry: Institut Français, 1977), pp. 368-369 and plate XII).
} 
of the inner instrument, but rather to the vast cosmic structure itself. This is a cosmological understanding of mind in which all levels within the manifested cosmos are classified as being within mind, whereas the transcendent level of Śiva is beyond mind. These ontic levels are used ritually, mapped onto the body and associated with different mantras ${ }^{46}$ : the purification of the body through the ritual process recapitulating the purification (and destruction) of the cosmos itself at the dissolution. This process is found in other texts as well such as the Svacchanda-tantra. ${ }^{47}$ There are, therefore, two senses of the mind as the term manas, the narrower sense of one of the ontic levels that comprise the inner instrument and the broader sense of the cosmos itself as comprising 'mind' and the mind's transcendence to higher ontic levels.

The term citta is used to indicate awareness and the verbal root cint is used to mean meditation or visualisation. Thus cintayet, third person singular optative, one should mediate, is common in tantric literature and is a synonym for dhyāyet, one should visualise, and vikalpayet, one should imagine. ${ }^{48}$ For example, in the Netra-tantra after the purification of body, the practitioner should visualise a process of the moon arising in his mind's eye, arising in the east, with the aid of the root mantra [OM JUM SAH], then he should meditate upon the fixing of mantras on the body in the ritual of making the body divine and fit for worship:

\footnotetext{
${ }^{46}$ For these cosmic-somatic correspondences see the diagrams in Brunner-Lachaux, Somaśambhupaddhati, pp. 690-89.

${ }^{47}$ Svacchanta-tantra 5.7-9: māyātattvam makāreṇa vidyātattvam kṣakāratah | rephena caiśvaram tattvam hakāreṇa sadāsivah //5.7// pranavena tathā śaktir nyasitavyā varānane / vyāpinīm samanām cordhve tatraiva tu viśodhayet //5.8// śodhayitvā kramenaiva mülamantreṇa suvrate / yojya ätmā pare tattve unmanātītasarvage //5.9//. 'The ontic level of the material substrate $(m \bar{a} y \bar{a})$ is associated with the syllable MA; the ontic level of [Śuddha] Vidyā with the syllable KȘA; the ontic level of İ́vara with RA; and Sadāśiva with the syllable HA. Then Śakti is to be placed with OM, O lovely faced woman, Śakti with OM and the drop. This is the ontic level of Śakti, [followed by] the form of Supreme Śiva. And so, one should purify [the levels named] all-pervading, with mind, and above that in the ontic category of Śiva, also with the syllable OM. This has been previously described with instruction [how it is to be performed]. Having purified [the levels in the body] in due order with the root mantra, $\mathrm{O}$ disciplined one, he unites the self with the highest ontic level which is beyond mind'.

${ }^{48}$ Jayākhyyasamhitā 10.26 (cintayet); 10.33b-34a (smaret); 10.46a (bhāvayet); 10.54a (dhyāyet); Skandapurāna 81.23 (vikalpayet). See Gavin Flood, 'The Purification of the Body in Tantric Ritual Representation,' pp. 33-34, Indo-Iranian Journal, vol 45, 2002, pp. 25-43.
} 
3.15. After [the purification of the body] he should visualise the series of phases of the rising moon, sprinkled with nectar [along with] the eastern image, in the three realities with the root [mantra].

3.16. Then he should fix the ancillary [mantras] on the body with both hands once more. With the practice of concentration, he should meditate the mantra [that gives him] a sense of self presence. ${ }^{49}$

'He should meditate' (cintayet) is used synonymously with 'he should imagine' (prakalpayet) and it is associated with another mental faculty of self-presence. Abhimāna is often rendered as 'pride' but I think we need to take it, in this instance, as not so much pride, which is a negative attribute, but a sense of who one is, one's own self presence, even though this is limited and for non-dual Śaivas, in the end a delusion. ${ }^{50}$ The object of the meditation practice is the mantra and its consequence would seem to be abhimāna. The text carries on in the next verse with the visualisation of the deity:

3.17.-20. Having assumed the cow gesture or also the lotus gesture, he should meditate on the Lord of gods in the self. [This self] is equal in splendor to ten million moons, resembling the fruit released from a jujube tree, having equal splendor to camphor, like jasmine, the moon, and cow's milk, resembling a [crystal] mountain. [The self is] adorned with white ornaments, with sandal, delightful camphor, saffron and so on, with limbs smeared with white sandal, powdered, grey camphor. [It is] submerged by many wide waves of nectar from the throbbing moon, situated in the middle of the lunar disc, single faced with three eyes. ${ }^{51}$

\footnotetext{
${ }^{49}$ Netra-tantra 3. 15-16 (f.6r): paścāt kalākalāpottham peyūṣena tu simcitam / mūrtipūrvam tṛtattve tu mūlenaiva prakalpayet // 3.15 // tato ['] ̣̣gāni karābhyām tu śarīre vinyāset punaḥ /mantrạ̣ caivābhimānam tu cintayed dhyānayogatah // 3.16 //. 3.15 b: simcitam] Na: secayet K; 3.15c: mūrtipūrvam tṛtattve] Na: mūrtibhūtam tritattvam K; 3.16a: tu] Na: ca K; vinyāset] Na: kalpayet $\mathrm{K}$.

${ }^{50}$ Isabelle Ratié, Le Soi et l'Autre: Identité, différence et altérité dans la philosophie de la Pratyabhijñā (Leiden: Brill, 2011), p. 206-208, note 76.

${ }^{51}$ Netra-tantra 3.17-20 (f.6r-f.7v): dhenumudrā tato badhvā padmamudrā tatathāpi vāa / dhyāyed ātmani deveśam candrakotisamaprabham // 17 // svacchamuktāphalaprakhyam sphațikādrisamaprabham /kumdeṃdugokșīre nibhaṃ himādṛsadrísam vibhum // 18 //śsbhrahāreṃdukāṃtāṃdisitabhūṣaṇabhūṣitam / sitacandanaliptāingam
} 
Here 'he should visualize' (dhyāyet) is synonymous with cintayet and prakalpayet. All three terms indicate a mental action orientated towards a spiritual elevation as, here, part of daily practice. One more example:

13.31. Now [the practitioner] should visualise God with many arms, the dancing Lord, the God bearing half [of his body] as Umā or bearing half as Viṣnu. ${ }^{52}$

Cintayet indicates a model of the mind in which it can be controlled and focused on a desired object. In view of the understanding that the mind takes the form of its objects, the pure object of the form of God functions to purify the mind. Cintayet is also close to the idea of worship. Thus, we read in the same chapter:

13.28. [The practitioner] should worship [the Sun] on the ground, in fire and in water, and at the tops of mountains, or where it shines in the mind. It bestows the fruit of desired magical accomplishments. ${ }^{53}$

When applied to the mind, 'one should worship' (püjayet) is equivalent to 'one should visualize' (dhyāyet, cintayet, vikalpayet).

Let us take stock for a moment. So far, we have explored three senses of the English word 'mind' in the Śaiva sources, firstly as citta and sometimes as manas, a term for the ordinary individual mind. We have seen that pre-philosophical Śaivism has a concept of the mind as inherently unstable and wandering, keeping a person from realization of a higher reality or journey to God. This is in consonance with the Patañjala yogic conception of mind as unstable and the definition of yoga as its cessation. Secondly, there is a cosmological understanding of the mind as the term manas, as being mapped onto the general ontic categories

\footnotetext{
karpūrakṣodadhūsaram // 19 // sphurac candrāmṛtasphārabahulormipariplūtam / somamaṇ̣̂alamadhyastham ekavaktram trilocanam // 20 //. 3.17a dhenumudrā tato badhvā] Na: mudrām caivāmṛtām baddhvā K.

${ }^{52}$ Netra-tantra 13.31: atho bahubhujam devam nātyastham cintayet prabhum / umārdhadhārinam devam viṣnur evārdhadhārinam //13. 31 //. 13.31a atho bahubhujam devam] $\mathrm{Na}$ : atha vā bahubāhum ca K; $13.31 \mathrm{~b}$ nātyastham $\mathrm{Na}$ : nādyastham K; 13.31c devam] ] Na: yadvā K; 13.31d viṣnur evārdhadhāriṇam] Na: viṣnor ardhārdhadhāriṇam $\mathrm{K}$.

${ }^{53}$ Netra-tantra 13.28 (f.32r): sthale 'nale jale caiva parvatāgreșu pūjayet / yatra vā rocate cittam icchāsiddhiphalapradam // 13. $28 / / .13 .28 \mathrm{~b}$ parvatāgreșu pūjayet] Na: parvatāgre prapūjayet $\mathrm{K} ; 13.28 \mathrm{c}$ cittam] $\mathrm{Na}$ : citte $\mathrm{K}$.
} 
and process of emanation. Thus, the ontic categories that comprise manifestation are regarded as being within mind (samanā), while transcendent Śiva and Śakti are beyond mind (unmanā). The term manas is also used for the human faculty, the inner faculty of perception whose object is thought; as the eye has forms and colours as its object, or the faculty of hearing perceives sounds, so the mind perceives thoughts. This is the Sāmkhya system adopted by the Saiva tantras where manas is part of a larger structure, the inner instrument, that also comprises the sense of self or ego and the intellect or higher mind that contains the compulsions, the predispositions towards experience in the world. These ideas are common in the prephilosophical literature, both in the Tantras regarded as dualist and those regarded as nondualist. Thirdly, we have verbal forms used in an instructional or injunctive sense that the practitioner should 'meditate' or 'bring to mind' the object of contemplation. Cintayet, 'one should think,' vikalpayet, 'one should imagine', and 'smaret', one should bring to mind or recall, are focused on the mind as a way of transforming self towards an eschatological goal.

(iii) Mind in Meditation

The mental activity of meditation indicated by the use of the third person optatives discussed above, focusses on the mind as a flow or continuity of thought as its object in the context of meditation (bhāvanā, dhāraṇā). Texts so far discussed, scriptures of the Saiva Siddhānta and Non-Saiddhāntika Śaivism, absorb a yogic model of the mind that accompanies their ritual systems and verbal forms such as cintayet, vikapayet, and smaret are used in the context of visualizations in the procedures of ritual systems with a focus on specific deities and their mantras. There is also at least one meditation manual outside of the ritual systems in which we find an understanding of mind as both object of meditation and as all-pervasive reality. This and related texts are within the Śaiva-Śākta tradition, with an emphasis on the Goddess abstracted to a non-anthropomorphic ideal of pure or all-pervading consciousness. This medit- 
ation manual is the Vijñannabhairava, an instruction that assumes the Goddesses of the Trika. This text can be classified, as Sanderson shows, as a Sakti Tantra in a tradition that includes the Mālinivijayottara-tantra, which for Abhinavagupta is the basic revelation of the Trika religion. ${ }^{54}$

The Vijñannabhairava - the God who is consciousness - presents a view of the mind, on the one hand as a process in the Yogin's ascent through the body and on the other as identified with pure consciousness in a spontaneous expansion that occurs in human experience. The text adopts the usual yogic model that the mind (cit) needs to be restrained (niruddham) $)^{55}$ and of the withdrawal of the mind from the sense spheres through closing off the senses by adopting a particular posture, using the hands to block the apertures or 'doors' of the face. The Yogin then perceives the 'drop' (binduh) internally, having penetrated between the eyebrows (bhrümadhya-), which then disappears leaving the Yogin established in the supreme condition. ${ }^{56}$ Again, when the Yogin casts the mind (manah kșipet) in the point at the crown of the head, then the mind will become 'out of use' (kșinavrttih) and he will attain a state of mind contrary to the usual, an unsignified condition (vailakșanyam). ${ }^{57}$ The commentary

\footnotetext{
${ }^{54}$ To briefly summarize Sanderson's work here, within the non-Saiddhāntika traditions, scriptures can be divided into the Mantra- and Vidyāpịtha. Within the latter group of scriptures, which are Śākta in orientation, there are three sub-divisions, the Vāma Tantras (such as the Vịnăsíkha), the Yāmala Tantras (such as the Brahmayāmala), and the Śakti Tantras. Of these, there are two groups, one forming the scriptural corpus of the Trika religion, expositing worship of the three Goddesses Parā, Parāparā and Aparā (such as the Siddhayogeśvarimata from which develops the Mālinīvijayottara), the other focused on worship of the Goddess Kālasaṃkārśinī or Kālī such as the Jayadrathayāmala, that also overlaps with the Kulamārga traditions (Kaula worship such as the Krama tradition). The Vijñannabhairava is a Śakti Tantra within the former subdivision of the scriptures of the Trika. See Alexis Sanderson, 'Śaiva Literature,' pp. 37-42.

${ }^{55}$ Vijñannabhairava with commentaries of Kșemarāja and Śivopadhyāya, edited by M.R.Śāstri (Bombay: Tatvavivechaka Press, 1918), v. 62.

${ }^{56}$ Vijñānabhairava v. 36: kararuddhadrgastena bhrübhedād dvārarodhanāt / dṛsțe bindau kramāt līne tanmadhe paramā sthitih // 'Due to stopping the doors [of the senses and consequent] penetration of the [space between] the eyebrows, by means of the weapon mantra and by sight stopped with the hands, seeing the drop which is gradually dissolved, the supreme state is established in the middle of that.' My understanding and translation of the text have been guided by Jaidev Singh's (Vijñānabhairava, Delhi: MLBD, 1963) and Lilian Silburn's (Le Vijñannabhairava (Paris: de Boccard, 1961) translations. On the hand gesture involved here, Silburn writes that this is a gesture (mudrā) taught by the master, involving the blocking of the senses by the hands: 'les dix doigts des mains s'opposent au fonctionnement des organes des sens, les pouces s'appliquent sur les oreilles, les index sur les yeux, les médius obstruent les narines tandis que les annulaires et les auriculaires servent à clore la bouche' (p. 86).

${ }^{57}$ Vijñānabhairava v. 51.
} 
by Śivopādhyāya tells us that vailakṣanyam means 'uncommon' (asamānya-) and that this is the condition or nature of being the supreme Bhairava (asāmānyaparabhairavarūpatā $).{ }^{58} \mathrm{We}$ might extend this idea to mean that while the ordinary mind is characterized by its ability to signify through language, the absolute state cannot be signified for we know it is beyond language from verse $14 .{ }^{59}$ The Yogin should meditate (vicintayet) the universe as being empty (śūnyabhätam) and through this the mind becomes dissolved (mano linnam) and absorbed in this void. ${ }^{60}$ This is to have freed the mind from thought construction and support. ${ }^{61}$ The text mostly uses the term manas but sometimes citta is a synonym; as manas can become dissolved so can citta (cittalayah sphuțam). ${ }^{62}$

But the mind not only recognizes itself as absolute consciousness through the process of meditation, but also that pure consciousness pervades all of experience. Thus, the elevation of mind (manorüghah) in sexual pleasure or the pleasure of eating and drinking, is the realization of absolute, Bhairava consciousness. Or having meditated (dhyātvā) the great joy that arises when, for example, one sees a relative after a long time, the mind becomes one with that experience (tan mano bhavet) ${ }^{63}$ Even ordinary acts of worship, such as ritual ablution (snānam) or worship, need to be understood as absolute consciousness. ${ }^{64}$ Once the indicators of distinction and individuality are dissolved, namely the sense of self ( $\bar{a} t m \bar{a})$, power (śaktih), intelligence (cetas $\bar{a})$, and mind (manah), Bhairava remains, ${ }^{65}$ which is the realization of the

\footnotetext{
58 Vijñ̄anabhairava, p. 44.

${ }^{59}$ Vijñānabhairava v.14: ... vyapadeștum aśakyāsav akathyā paramārthatah. ' '... according to the supreme reality [the absolute state] cannot be told, in this matter there is an inability to name.' This absolute is beyond predicates, being that which speech cannot speak. Cf. the Netra-tantra, 8.3c: '[God is that] which speech cannot speak' (yan na vāg vadate).

${ }^{60}$ Vijñ̄anabhairava, v. 58.

${ }^{61}$ Vijñānabhairava, v. 108: nirārdhāram manah kṛtvā vikalpān na vikalpayet / tadātmaparātmatve bhairavo mrgalocane //. Having made the mind to be without support, he will not imagine thought construction, then there will be [the state of] Bhairava in the condition of the supreme self, which is the self [entered into] that, $\mathrm{O}$ deereyed one.

62 Vijñānabhairava, v.115.

${ }^{63}$ Vijñānabhairava, vv. 69-71.

${ }^{64}$ Vijñānabhairava, vv. 153-54.

${ }^{65}$ Vijñanabhairava, v.138: 'When the four - mind, intellect, power, and self - are dissolved, O dear one, then the body which is Bhairava [remains]'. mānasam cetanā śaktir ātmā ceti catuștayam / yadā priye parikṣiṇam tadā tad bhairavam vapuh. Śivopādyāya tells us that here cetanā means buddhi, śakti means prāna, while ātmā refers
} 
emptiness of the universe, of pure consciousness and of the Goddess. Indeed, wherever the mind goes, there is the condition of Śiva. ${ }^{66}$

The Vijñanabhairava would seem to be a standalone text on meditation, not directly linked to a mantra system of deity visualisation. The Mālinivijayottara also contains meditation practices, such as meditation upon the elements earth, air, water, fire and ether, imagining the body wreathed in flame and so on, ${ }^{67}$ and an account of transferring consciousness out of the body as an act of will at death, namely utkrānti translated as yogic suicide. ${ }^{68}$ But unlike the Vijñanabhairava, it is rooted more clearly in the Trika tradition and its ritual system, developing out of the Siddhayogeśvarimata, and its mandala is for the Trika's goddesses. ${ }^{69}$ Its concept of mind is in consonance with the other texts we have encountered here; there is an intimate relation between mind and breath, so calming the breath is calming the $\operatorname{mind}^{70}$ and in this way there is elevation to higher cosmological levels. As with other Tantras we find the idea of casting the mind and placing it in a concentrated way, with a focus on inner experience. For example, in the text we have the following instructions:

16.48-51. The Yogin, having bound himself in the lotus posture, remembering the supreme seed syllable, should place the mind between the eyebrows, [focusing on the place] in front, outside. Having closed his eyes, his self enraptured, abandoning sound and vision, he sees there the self, established [at the place] twelve fingers length [from the eye centre]. There he should make the mind firm, then after three months [practice],

to the particular experient (pramātr); once dissolved there remains 'the inner joy in one's own experience' (antah svānubhavānandā).

${ }^{66}$ Vijñānabhairava v. 116: yatra yatra mano yāti bāhye vābhyantare'pi vā / tatra tatra sívāvasthā vyāpatkatvāt $k v a$ yassyati // 'Wherever the mind goes, whether within or without, there is the condition of Śiva. Due to its allpervasiveness, where else may [the mind] go?'

${ }^{67}$ Vasudeva, Yoga, p. 319.

${ }^{68}$ Vasudeva, Yoga, pp. 437-45.

${ }^{69}$ Vasudeva, p. xxxix. He describes the text as follows: 'The Trika's three Goddesses Parā, Parāparā, and Aparā with their consorts Navātmabhairava, Bhairavasadbhāva and Ratiśekharabhairava are the high deities in the centre of the Mälinīvijayottara's maṇalala, surrounded by the alphabet deities Mālinī and Śabdarāśibhairava.' Also see Alexis Sanderson, 'Maṇạala and the Āgamic Identity in the Trika of Kashmir,' André Padoux (ed.), Mantras et Diagrammes Rituels dans l'Hindouisme (Paris: CNRS, 1986), pp. 169-207.

${ }^{70}$ Vasudeva p. 371. 
with the divine eye he sees the form of splendour, immoveable, resplendent like the moon, completely full. Having seen that self, he attains the divine knowledge of time. ${ }^{71}$ Here the text describes a meditation practice and the consequent inner vision of a form of light, the mind's focus and object. Thus, meditation involves focusing the mind within and perceiving the flow of the objects of consciousness. Vasudeva discusses the term cintā to refer to this flow as an object of awareness. Terminology one might expect to find in this regard are cittasantāna and cittasantati, the flow of the mind, but they only occur in two Yoga texts, not in the Saiva Tantras to my knowledge. ${ }^{72}$ But the inner vision described in the Mălinī is the object of consciousness that the mind settles upon or is the focus that, with the cutting off of the senses, leads to a vertical ascent from the eye centre to Siva at the crown of the head. With practice, the Yogin will obtain omniscience by making the mind firm. ${ }^{73}$

\section{The Śaiva-Śākta Philosophical Discourse on Mind}

Emerging from the ambient discourse a distinctive philosophy of mind develops within a Śaiva-Śākta ethos that is idealistic in its orientation, in the weaker version meaning that there can be no account of the world independent of an account of consciousness, for the world is an emanation of cosmic mind, and in the stronger version meaning that the world is consciousness. This philosophical trajectory comes to be articulated in the Pratyabhijñā or Recognition school of philosophy. While Abhinavagupta presents systematic arguments for Pratyabhijñā idealism,

\footnotetext{
${ }^{71}$ Mālinīvijayottara 16. 48-51: 16.48ab: baddhvā padmāsanam yogī parābījam anusmaran / 16.48cd: bhruvor madhye nyasec cittam tadbahị kị̣ cid agratạ / 16.49ab: nimīlitākṣo hṛ̦tâtmā śabdālokavivarjite / 16.49cd: paśyate puruṣam tatra dvādaśāngulam āyatam / 16.50ab: tatra cetah sthiram kuryāt tato māsatrayopari / 16. 50cd: sarvāvayavasampūrṇam tejorūpam acañcalam / 16.51ab: prasannam indusaṃkāśam paśyati divyacakṣuṣā / 16.51cd: tam dṛștvā puruṣam divyam kālajñānam pravartate. Cf. the Vijñānabhairava v. 37.

${ }^{72}$ Cittasantāna occurs in the Amrtasiddhi 8.18 ( na vetti cittasantānam ...) and cittasantati in the Amaraughaprabodha $4 \mathrm{ab}$ yaccittasantatilayah sa layah pradiștah.

${ }^{73}$ Mālinīvijayottara $18.40 \mathrm{~cd}$ : tatra cittam sthirīkurvan sarvajñatvam avāpnuyāt. 'He may attain omniscience making the mind firm there.'
} 
especially against the Buddhists ${ }^{74}$ others in this tradition are less argumentative and more expository, stating the truths of the doctrine within the parameters of its own discourse. Kșemarāja, writes commentaries on the inspired texts of Vasugupta, the pithy and obscure Śiva-sūtras and Spanda-kārikās that lays some of the foundations of this way of thinking. The opening of the Śiva-sütras simply states: caitanyam àtmā, the self is the mind or consciousness. Kșemarāja comments that there is nothing outside of consciousness:

Here [in this world], because of the non-existence of a being that is not perceived, the activity of supreme consciousness has the nature of being common to all. The conscious being, who is free in all-knowledge and action, perceives. His being is consciousness which is said to be completely full freedom which comprises a relation between allknowledge and action. And that is only of the Lord Supreme Siva. [This is the case for all beings] from those who are dependent on him to those up to [the level of] the not dependent. ${ }^{75}$

There is no existence (sattvam) that is not perceived (acetita-) is a statement of idealism, that there is no reality outside of consciousness and this supreme consciousness (citih) is common to all. Although the verb cetayate is a causative àtmanepada of cit, I have taken it in an active sense with the subject of the verb as the conscious being (cetanah) who is free to attain all knowledge and action. In other words, the Supreme Siva is in reality the ordinary subject of experience, although the ordinary subject appears to be dependent on him. This contrast between freedom (svatantra-) and dependence (paratantra-) maps on to the reality of pure consciousness and illusion of the bound self. In truth there is no reality outside of consciousness and this consciousness is freedom. Although he refers to the Lord Śiva, in this passage

\footnotetext{
${ }^{74}$ Arguments are found in particular in Abhinavagupta's commentary on Utpaladeva's Verses on the Recognition of the Lord, the İśvarapratyabhijñāvimarśinī, analyzed in great detail by Ratié, Le Soi et l'Autre, e.g. pp. 257-64; 289-306.

${ }^{75}$ Śivasūtra-vimarśinī, v.1, p. 4: iha acetitasya kasyāpi sattvābhāvāt, citikriyā sarvasāmānyarūpā iti, cetayate iti cetanah sarvajñānakriyāsvatantrah, tasya bhāvah caitnayạ̣ sarvajñānakriyāsambandhamayam paripūrnạn svātnatryam uccyate. (My translation, guided by Singh and Silburn.)
} 
Kṣemarāja uses the feminine noun citi to refer to absolute consciousness as well. This is significant because it aligns ultimate reality with the Goddess whose nature is citi. Indeed, he picks up this term in the Pratyabhijñăhrdaya where he identifies the limited individual mind with the cosmic mind of the Goddess. The opening verse states:

Consciousness, due to her own freedom, is the reason for the actualization of the universe. $^{76}$

In his auto commentary Kșemarāja explicates these terms: 'of the universe' he says, 'means from the level beginning with Sadāsiva to the earth' (i.e. the total cosmos) and 'consciousness'(citi) means 'the Goddess (bhagavatī) whose form is absolute power (parāśaktirūpā)' Freedom is constitutive of awareness itself and inseparable from it: to be the one reality of consciousness is to be free. Particular or individual consciousness is but a contraction of this universal Consciousness-Goddess:

That very consciousness, descended from the level of [universal] consciousness, becomes limited consciousness contracted to [the form of] its objects. ${ }^{77}$

In his commentary he expounds the meaning:

That which is called consciousness is not another thing, but only the Goddess herself. When having hidden her own nature she manifests contraction, then she is divided in two. Although shining [she still contracts and], having produced the quality which is contraction, she shines forth [again] with the predominance of consciousness, and whenever [she subordinates consciousness then] contraction predominates. In one case (pakșe) with the innate predominance of consciousness, there is [also] the predominance of light alone [and this is] the condition of the experient of consciousness (vijñankalatā). With the predominance of [both] light and awareness [we have] the

\footnotetext{
${ }^{76}$ Pratyabhijñāhṛaya sūtra 1: citih svatantrā viśvasiddhihetuh.

${ }^{77}$ Pratyabhijñāhrdaya sūtra 5: citir eva cetanepadād avarūạhà cetyasamkocin̄̄ cittam.
} 
condition of the experient of knowledge (vidyāpramātrtāa). And in the next case (tatrāpi), with the gradual attenuation of contraction, there are the forms of İsa, Sadāśiva and Anaśrita. When consciousness is predominant, acquired through the effort of concentration, the experient of the pure cosmic course is drawn gradually [to higher levels]. But when contraction predominates, the experient's [fields of perception] are emptiness and so on. Therefore, in this context that very consciousness (citir eva) is the form of contracted subjectivity. 'Descended from the level of [universal] consciousness' [means] intentionality towards objects (arthagrahanonmukhī). ${ }^{78} \mathrm{By}$ 'object of consciousness' [is meant objects such as] blue, happiness and so on. 'Being contracted' [means] consciousness contracted by both [internal and external kinds of] contraction. ${ }^{79}$

I have cited this at length because it presents this doctrine in a pithy summary of the entire philosophy. The term citi elevates the mind to the highest level of the cosmos which is yet the totality of everything and pervades all. The limited mind of sentient beings, who are graded in a hierarchy depending upon their degree of awakening, is but a contraction of this universal power such that there appears to be a conformity of particular consciousness to its objects or realms. This is quite a radical departure from the Śaiva Siddhānta scriptures where the self is transcendent, and the mind is the product of the material substrate (prakrtih) as we saw in our earlier discussion. Here the cosmic mind, which is the Goddess, manifests the universe and the

\footnotetext{
78 I have interpreted the phrase arthagrahanonmukhi simply as 'intentionality towards objects' taking 'intentionality' in the phenomenological sense of consciousness taking an object.

${ }^{79}$ Pratyabhijñāhrdaya sūtra 5 commentary: na cittam nāma anyat kimcit api tu saiva bhagavatī tat | tathā hi sā svam svarūpam gopayitvā yadā saṃkocam grhṇāti tadā dvaȳ gatih kadācit ullasitam api saṃkocam guñ̄krtya citprādhānyena sphurati kadācit samkocapradhānatayā | citprādhānyapakșe sahaje prakāśamātrapradhānatve vijñāanākalatā prakāśaparāmarśapradhānatve tu vidyāpramātrțtā $\mid$ tatrāpi kramena samkocasya tanutāyām iśasadāsivānāśritarūpatā | samādhiprayatnopāriite tu citpradhānatve śuddhādhvapramātrțtā kramāt kramam prakarșavatī | saṃkocaprādhānye tu śūnyādipramātrțtā | evam avasthite citir eva sạ̣kucitagrāhakarūpā cetane-

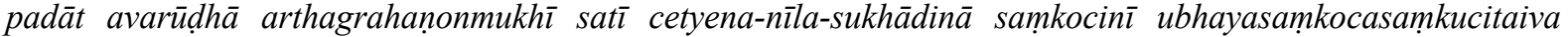
cittam.
} 
beings within it, which is a contraction of her nature, and makes the particular mind correspond to a world of experience.

Citi as the supreme consciousness Goddess has other synonyms, most notably samvit. Consciousness (samvit) is self-manifesting in its objects (samvedya).$^{80}$ Abhinavagupta says that this consciousness (samvit) is subjectivity (pramātrtâ), which in everyday speech means 'Caitra is a subject' and so refers to the first person singular, the 'I.' This subjective awareness is reflexive (vimarśah), aware of its awareness, and also the light of consciousness (prakāśa), within which apparently distinct objects of consciousness appear, which from the ultimate perspective are only constituted within consciousness. ${ }^{81}$ A number of terms for an ultimate reality of consciousness would seem to be synonymous in philosophical Śaiva non-dualism, namely cit, citi, samvit and also vijñāna.

The Śaiva-Śākta non-dualists thus have an understanding of the mind distinct from the dualist Tantras and their commentators. The idea of citi as expounded in the Pratyabhijñ $\bar{a}-$ hrdaya as absolute, cosmic power and consciousness is different from the dualist notion of a restricted and restrictive organ of human limitation. We can see this in the particularity of terms used. In the context of the Nyāya school of philosophy, Chakrabarti translates manas as 'inner sense' because it perceives inner objects in a parallel way to the eye perceiving external objects or colours. ${ }^{82}$ In phenomenological terms we might say that the inner sense takes the flow of thoughts and memories as its direct object of perception. Manas in the Śaiva Siddhānta texts is the inner sense, part of the inner instrument at the self needs to be aware of anything. This is contrast with non-dualist interpretation of the Pratyabhijñā where manas is taken in a broader

\footnotetext{
80 e.g. Abhinavagupta Tantrāloka 10.27-28ab; bhāvasya vedyatā saiva samvido yah saudbhavah / arthagrahanarūpam hi yatra vijñānam ätmani // samavaiti prakāśyo'rthas tam praty eșaiva vedyatā. Quoted in Ratié, Le Soi et l'Autre, p. 330. 'An object of knowledge to be of an existing thing is only the appearance of consciousness. For where consciousness is in the self, whose nature is the grasping of the object, the object to be illuminated is innate [within consciousness]. This condition of an object of knowledge is only in him.' [My translation guided by Ratié's p. 330 note 47].

${ }^{81}$ Ratié p. 627, quoting Abhinavagupta, İśvarapratyabhijñāvimarśinīvivrtti, vol. 1, p. 108.

${ }^{82}$ Chakrabarti, Classical Indian Philosophy of Mind, p. 104.
} 
way to be identical with the absolute consciousness that is Siva. For example, in the Netratantra, manas goes to the condition of absolute consciousness:

With 'I am not and there is no other' there is no object of meditation here; [the Yogi's] mind (manah) has gone to the sameness of flavour [with Siva], dissolved in the condition of joy. ${ }^{83}$

Interestingly, the Nepalese recension of the text has jũānam, rather than manah, that we might render here as 'cognition'. Here manas is more than simply the inner sense that takes internal intentional objects but is identified with highest absolute, a liberating cognition.

This idea that the unliberated mind (manah) is constrained yet once freed from constraint, realizes itself as identical with the supreme reality is a theme rearticulated through the history of the Pratyabhijñā. The seventeenth or eighteenth century Cittānubodhaśāstra by Bhāskarakaṇtha rearticulates the non-dualist philosophy of the earlier tradition, although informed by the terminology of Advaita Vedānta. Here the mind as the inner sense, manas, is simply consciousness that has been restricted by the turning of imaginary conception ('the mind is consciousness whose nature is the turning of imaginary conception'). ${ }^{84}$ The truth of the world is entirely consciousness only (cinmātram) which shines in its own light (svabhās $\bar{a}$ bhäti) even in object of consciousness (cetyam) or the midst of the flow of intentional objects (cintāmadhye). ${ }^{85}$

\section{A Historical Conclusion}

What are we to conclude from this survey? Referencing Herman Jacobi who argues that Yoga and Sāmkhya have distinct models of the mind, Vasudeva observes that along with the

\footnotetext{
${ }^{83}$ Netra-tantra 8.40: nāham asmi na cānyo'sti dhyeyam cātra na vidyate / ānandapadasaṃlīnam jūānam samarasigatam // 40 //.

${ }^{84}$ Cittānubodhaśāstra 2.292a com: manaḥ sañkalpavrttirūpam cittam. I thank the anonymous reader for drawing my attention to this text.

${ }^{85}$ Ibid. 3.116-117.
} 
rigid cosmological hierarchy of Sāmkhya, there is an idea of the mind in the Yoga tradition as all-pervasive, which the Śaiva scriptures inherit or adopt. This idea of citta as 'a pervasive entity which is capable of expanding and retracting its functions ${ }^{96}$ goes back before Patañjali born witness to in a quotation in the Yogasütrabhāṣya, where Vācasaptimiśra attributes the origin of Yoga to Svāyambhū, and this pre-Patañjala tradition influences texts such as the Mālinīvijayottara. ${ }^{87}$ Developing this idea, the textual material I have presented suggests that we can conclude the following. Firstly, following Vasudeva and Goodall, there is a strong Sāmphya influence on the Śaiva Siddhānta scriptures as we see with the Mrgendra, the Matangaparameśvara, and other tantras. To the twenty-five Sāṃkhya ontic categories, the Śaivas add a further eleven to the hierarchical sequence. Here mind as manas is a lower function of the cosmological hierarchy, the inner sense that Chakrabarti identifies. Secondly, these scriptures and their commentators are also influenced by the classical Yoga of Patañjali in which the mind, and the term citta is used, is unstable, wandering, and difficult to control. But through practice, especially breath control, the mind can be brought to order and subdued. Once there is a withdrawal of awareness from the spheres of the senses, then the Yogin can develop an interiority in which the mind is cast to an inner focus of concentration that propels it into a vertical ascent. This vertical ascent through the cosmos that is mapped onto the body is, moreover, classified as being within the realm of mind (samanā) or beyond mind (unmanā): the Yogin's purpose is transcendence of mind and cosmos. A further transformation is that in Śaiva tantric practice, meditation as visualization develops to a high degree of sophistication and is integrated into the ritual system. Here dhyāna comes to mean visualization. All this we find in the theistic and dualistic Śaiva Tantras along with their commentators. Śaiva orthodox

\footnotetext{
${ }^{86}$ Vasudeva, The Yoga of the Mālinivijayottaratantra, p. 430. I was unable to access Jacobi's text at the time of writing.

${ }^{87}$ Vasudeva, The Yoga of the Mālinīvijayottaratantra, p. 425. Referencing Jacobi, Vasudeva observes how his painstaking work has enabled us to identify an original yoga that 'employs the terms manas, buddhi, citta and cetas synonymously to denote the locus of psychic events.'
} 
doctrine and practice absorbs Yoga into the ritualistic system, but which cannot replace that system as the main route to redemption in which the material substance of karmic residues are cleaned through action and the grace of Śiva.

But as we move into the non-Saiddhāntika realm, thirdly, a new understanding of mind seems to develop, one in which the mind (as citta or manas) is identified with an all-pervading reality of consciousness (caitanya, cit) identified with the self $(\bar{a} t m \bar{a})$. This cosmic mind is not simply located at the top of the cosmical hierarchy but pervades the hierarchy. This model of mind as all-pervasive we find in the non-Saiddhāntika inspired texts of Vasugupta (the Śivasūtras and Spanda-kārikās) and in the Śaiva-Śākta philosophies that comment upon the Śaiva scriptures. We also find this idea in the Śakti tantras, particularly the Vijñannabhairava and other Goddess focused texts such as the Brahmayāmala, as we have seen. It is the idea of the all-pervasive mind that comes to be thematised by the non-dualistic philosophers such as Abhinavagupta and Kṣemarāja. We might even say that the Goddess orientated traditions, the Sákta traditions, are more saturated by the idealistic model of the mind as all-pervading: the all-pervading mind is in fact the Goddess. There is presumably a link between this theology and the model of the person in which the Goddess embodied as the nectar of immortality, pervades the body through yogic practice: Wernicke-Olesen has called this a 'Śākta anthropology.' 88

Lastly, we need to consider the relationship between Buddhism and the Hindu tantric traditions. It has been shown that the Śaiva tantras directly influence the Buddhist, ${ }^{89}$ but also

\footnotetext{
${ }^{88}$ Wernicke-Olesen, Bjarne and Silje Lyngar Einarsen. 'Übungswissen in Yoga, Tantra und Asketismus.' In Almut-Barbara Renger and Alexandra Stellmacher (eds.). Übungswissen in Religion und Philosophie: Produktion, Weitergabe, Wandel. Berlin: Lit Verlag, 2018: 241-57.

${ }^{89}$ E.g. Alexis Sanderson, 'Vajrayāna: Origin and Function,' in Buddhism Into the Year 2000. International Conference Proceedings (Bangkok and Los Angeles: Dhammakaya Foundation, 1995), pp. 89-102; Harunaka Isaacson, 'Initiation (abhișeka) in the Higher Buddhist Tantric Systems,' p. 263, in Astrid Zotter and Christoff Zotter (eds.), Hindu and Buddhist Initiations in India and Nepal (Wiesbaden: Harrassowitz Verlag, 2010), pp. 261-79.
} 
that hațayoga's origins are in Buddhism..$^{90}$ Except in situations where explicit borrowings can be established, as with the Buddhist Anuttara Yoga Tantras from the Śaiva corpus, it is often difficult to establish specific instances of influence. But we might suggest that the Abhidharmic understanding of mind influences classical Yoga (see footnote 6 for references) and thereby has indirect influence on the Śaiva Tantras' understanding of citta. This is the idea of the mind as needing to be controlled to stop suffering. Here the term citta is used to mean the individual mind that is uncontrolled, as we have seen. But in one or two places in the early Buddhist scriptures, the Pāli Canon, there is a more positive understanding of mind as luminous: 'The mind, O Monks, is brightly shining (pabbasara-cittam)' says the Buddha in the Ariguttara Nikāya. ${ }^{91}$ This early idea of the brightly shining mind goes into Yogācāra Buddhism and Tathāgatagarbha doctrine thereby becoming an ultimate reality. ${ }^{92}$ Alongside the pan-psychism of the Yogācāra, Madhyamaka philosophy presents a model of the mind as empty and emptiness being the heart of reality. This idea of emptiness seems to have had some influence on the Vijñānabhairva's meditations on the cosmos as empty. And associated with the Buddhist notion of emptiness, we have the idea of the mind attaining its natural, calm state which is to be identified with the Buddha. It is this idea that Guenther highlights as the main characteristic of the tantric Buddhist understanding of mind and that echoes in the Vijñannabhairava's identification of the universe with emptiness in verse 58. Lastly, perhaps, we need to reflect not only on the historical picture that these readings of the texts present, but also on the philosophical implications of such inquiry.

\footnotetext{
90 James Mallinson, 'Hațhayoga's Early History: From Vajrayāna Sexual Restraint to Universal Somatic Soteriology,' in Gavin Flood (ed.), The Oxford History of Hinduism: Hindu Practice (Oxford: Oxford University Press, 2020), pp. 177-97.

${ }^{91}$ Añguttara Nikāya 1.8-10.

92 Jikido Takasaki, A Study of the Ratnagotravibhāga (Uttaratantra), Being a Treatise on the Tathāgatagarbha Theory of Mahāyāna Buddhism (Rome: Instiuto Italiano per il Medio ed Estremo Oriente, 1966), p. 163.
} 


\section{A Philosophical Conclusion}

Two distinct, although related, problematics in the history of Western philosophy have been the problem of personal identity and the philosophy of mind. There is a vast literature on each, but bringing these two problems to bear on the material I have discussed highlights certain concerns in the Śaiva-Śākta traditions because the two issues encapsulated in those discussions, namely the problem of what constitutes identity of a person through time (e.g. bodily continuity and/or memory have been two candidates) and what the relationship is between the mind and the body (e.g. dualism, epiphenomenalism, identity theory and so on). In the context of medieval India these problematics are arguably conflated in the sense that the question of identity or continuity through time is linked to the question of the mind and what persists. For Buddhism there is no personal identity because the person is constructed from constantly changing causes and conditions. ${ }^{93}$ For Śaiva Siddhānta, personal identity is constrained by the weight of the cosmological process bearing down upon a person and while the mind as lower emanation of nature changes with different causes under different conditions, the self does not. The non-dual Śaivas also accept the notion that the self is unchanging and that it is the lower emanations of mind and body that are subject to causal effects. Mind in this sense is a property of the self rather than the subject of experience. Abhinavagupta's challenge to the Buddhists is just this, that while the flow of perceptions might change, there needs to be an unchanging subject for whom the flow of perceptions is its object. ${ }^{94}$ But in contradistinction to the Śaiva Siddhānta theologians, Abhinavagupta's unchanging self is nothing other than the supreme Śiva himself, or pure consciousness without distinction and identified also with the Goddess, especially by Kṣemarāja.

\footnotetext{
${ }^{93} \mathrm{~J}$. Duerlinger, Indian Buddhist Theories of Persons. Vasubandhu's 'Refutation of the Theory of a Self' (London: Routledge, 2003).

${ }^{94}$ Íśvarapratyabhijñāvimarśinī of Abhinavagupta, 1.6.5, pp. 313-14, cited in Gavin Flood, The Truth Within: A History of Inwardness in Christianity, Hinduism, and Buddhism (Oxford: Oxford University Press, 2013), p. 151; Ratié, Le Soi et l'Autre, for example, on the auto luminosity of consciousness, pp. 38-45.
} 
So if, as Ganeri claims, philosophy is ahistorcial in the sense that the goal of the philosopher is to decontextualize (and so philosophy and the history of philosophy are quite distinct), then the same philosophical problematics will emerge in different cultural contexts. ${ }^{95}$ I think this is partly true in the sense that analogous problematics emerge in different civilizations, but only partly, because philosophical problems have their own unique histories. While it would be unfair to project issues of Western philosophy onto the Indian context, it is nevertheless fruitful to raise questions of identity and the philosophy of mind in distinct cultural locations because it highlights the concerns of those philosophers and brings into sharper profile the issues at stake. We have seen above that the category of the mind translates a number of terms in Hindu Tantrism, including citta, manas, and vijñanna, and that the mind here has a negative evaluation in that it prevents the development of a person's fullness through its distracting capacity, driven by desire. And yet the mind is also the vehicle for change and through its use in meditation and ritual procedures, the self can be transformed to realize its innate divinity and, for the non-dual Śaivas, its spontaneous freedom.

Paul Ricoeur introduced a distinction between two kinds of personal identity, namely sameness through time, that he calls idem, and selfhood or ipse, that entails a continuity of narrative. To be a capable person, in Ricoeur's view, is to be able to develop four stages in which the self recognizes itself as a self rather than an object, the self as the speaking subject has the capacity to act, the self has a narrative identity, and the self inevitably acts ethically and seeks ways to do so. ${ }^{96}$ As a result of this developmental process, a person is therefore characterized as a creature with a set of lasting dispositions that allow him to be recognized as a person, this Ricoeur calls character, along with the constancy of the self, revealed in the act of promising: a person is a person because of character and the ability to make, and break, a

\footnotetext{
95 Jonardon Ganeri, Philosophy in Classical India (London: Routledge, 2001), p. 4.

${ }^{96}$ Paul Ricoeur, Oneself as Another, translated by Kathleen Blamey (Chicago: Chicago University Press, 1992), pp. $113-68$.
} 
promise. ${ }^{97}$ So in this framing of the discussion, the problem of the mind-body relation is transformed into the problem of what constitutes a self through time. It is a question of the person rather than mind, linked to the question of agency and the 'who' of action. ${ }^{98}$ Placed in the context of the Śaiva-Sākta philosophers, we can see resonances with the Ricoeur position in the sense that the subject recognizes itself as subject and indeed, this is the whole orientation and goal of the Pratyabhiñā school, for the self to recognize itself as unlimited and unconstrained. But Ricoeur's second criterion of being a capable person, narrative identity, is not explicitly recognized as being of value. The self is unchanging and eternal, so what changes is the body and the mental faculty, change driven by innate dispositions within the buddhi that constrain the empirical person into what they are. And the capacity to act is not actually a property of the individual self, who, as we have seen, is dependent (paratantra-) on the higher power. Rather the liberated self is spontaneously free, with an inner freedom as realization of the self's identity with God. The full description of this argument has been very ably achieved by Ratié, but extensions of the argument and engagement with a comparative philosophy has yet to be developed. Guenther went some way to developing a comparative philosophy of mind in his analysis of Buddhist tantric material in Tibetan, especially his account of 'appearance' and the analysis of perceptual situations, ${ }^{99}$ and others have argued for the contemporary philosophical relevance of a Buddhist philosophy of mind, ${ }^{100}$ which has even begun to influence analytic philosophy. ${ }^{101}$ Sixty years on, Guenther's study stands as a landmark in the history of tantric scholarship and the serious philosophical engagement with Buddhist tantric ideas that he initiated needs to be developed further in new directions. A Hindu tantric

\footnotetext{
${ }^{97}$ Ricoeur, Oneself as Another, pp. 118-20.

98 See Frazier, Hindu Worldviews, pp. 195-96.

${ }^{99}$ Guenther, 'The Concept of Mind in Tantric Buddhism,' p. 266-67.

${ }^{100}$ E.g. Jay Garfield, Engaging Buddhism: Why it Matters to Philosophy (Oxford: Oxford University Press, 2015), pp. 37-40.

${ }^{101}$ Kris McDaniel, The Fragmentation of Being (Oxford: Oxford University Press, 2017), pp159-60, 174-75; and in an earlier generation, Derek Parfit, Reasons and Persons (Oxford: Oxford University Press, 1984), pp. $502-03$.
} 
philosophy of mind and philosophy of the person are clearly topics of comparative philosophical interest that might yet provide resource for contemporary debate. 


\title{
Acknowledgments
}

I would like to offer thanks to the anonymous readers for their extremely helpful reports, which gave me cause for thought about future directions for this material. I would also like to take this opportunity to thank my colleagues and friends Professor Alexis Sanderson for his unparalleled historical and philological work on these traditions, scholarship that has allowed reflection such as this to take place, and Dr Bjarne Wernicke Olesen whose work on the Śākta religions brings together Indology and Anthropology in mutually enriching ways.

\section{References}

\author{
Abbreviations \\ $\mathrm{K}=$ Netra-tantra $(\mathrm{KSTS}$ edition $)$ \\ $\mathrm{Na}=$ Amrteśatantra (Nepalese recension of the Netra-tantra)
}

\section{Sources}

Amrteśatantra, $\mathrm{Na}=$ National Archives of Nepal, Kathmandu, MS 1-285, Nepal German Manuscript Preservation Project, Reel No. B 25/5. Palm Leaf; Nepalese variant of protoBengali script, 1200 CE (= Nepālīya Saṃvat 320). Also see Netra.

İsvarapratyabhijñāvimarśinī by Abhinavagupta. Ed and translated by R.C. Dwiwedi, K.C. Pandey, and K.A. Subramania Iyer as Bhāskarī, vol. 1 (Delhi: MLBD, 1986 [1938]).

Kiranatantra. Dominic Goodall, Bhațta Rāmakanțha's Commentary on the Kiranatantra vol. 1, chapter 1-6. Pondichéry: Institut Français, 1998. 
Cittānubodhaśatra of Bhāskarakaṇtha. Stanislav Jager, Bhāskarakaṇthas Cittānubodhaśāstra: Kritische Edition der ersten drei Kapitel nebst Erstedition des Autocommentars (Marburg: Indica et Tibetica Verlag, 2018).

Tantrāloka of Abhinavagupta with the commentary (-viveka) of Rājānaka Jayaratha. Mukund Rām Śāstrī (ed.) vol.57 Srinagar: KSTS, 1938. E-text: converted from devanagari typesetting files prepared by Dr. S. Malaviya by computer programs developed by Muktabodha. The Muktabodha Indological Research Institute under the direction of Mark S. G. Dyczkowski. Catalogue no. M00093, 2007.

Netra and Netroddyota: Netratantra with the commentary (-uddyota) by Ksemarāja, edited by Madhusūsan Kaul Śāstrī, vols 1 and 2, Kashmir Series of Texts and Studies, 46, 59. Bombay: Tatva Vivechaka Press,1926,1939. Also see Amṛteśatantra.

Niḥśvāsatattvasamhitā, edited by Dominic Goodall, The Niśvāsatattvasamhitā, the Earliest Surviving Śaiva Tantra, vol. 1. Pondichéry: Institut Français de Pondichéry, 2015.

Pratyabhijñāhrdaya by Kșemarāja, edited by J.C. Chatterji KSTS vol 3 (Srinagar: Research Department, Jammu and Kashmir State, 1911). English translation, Jaideva Singh (Delhi: MLBD, 1963).

Matañgaparameśvara-tantra (Kriyāpāda, Yogapāda, et Caryāpāda) avec le commentaire de Bhațta Rāmakaṇtha, edited by N.R. Bhatt (Pondichéry: Institut Français d'Indologie, 1982).

Mrgendra. Vidyāpāda and Yogapāda, with the commentary (-vṛtti) of Bhaț̣a Nārāyaṇakaṇṭha. Madhusudan Kaul (ed.). Srinagar: KSTS 50, 1930. French translation by Michel Hulin, 
Mrgendrāgama: sections de la doctrine et du yoga avec la vṛtti de Bhațta Nārāyaṇakaṇtha et la dipika d'Aghorásivācārya. Pondicherry: Institut Français d'Indololgie, 1980.

Raurāvāgama edited by N.R. Bhatt, Raurāvāgama vol 1. (Pondichery: Institut Français de Pondichéry, 1985).

Vijñānabhairava with commentaries of Kṣemarāja and Śivopadhyāya, edited by M.R.Sāastri (Bombay: Tatvavivechaka Press, 1918). English translation by Jaideva Singh, Vijñānabhairava, Delhi: MLBD, 1963 and French translation by Lilian Silburn, Le Vijñānabhairava, Paris: de Boccard, 1961.

Śiva-sūtras of Vasugupta with vimarśin̄ of Ksemaraja, ed. J. C. Chatterji (Bombay: Tatvavivechaka Press, 1911. French translation L. Silburn, Paris 1980. English translation, Jaideva Singh, Motilal Banarsidass, Delhi, 1979.

Suprabhedāgama. No editor ascribed. Devakottai: śivāgama siddhānta paripalana sañgham, 1931. E-text: created from a devanagari electronically typeset file, the Muktabodha Indological Research Institute under the direction of Mark S. G. Dyczkowski. Catalogue no. M00090, 2007.

Somaśambhupaddhati, edited and translated by Hélène Brunner-Lachaux, Somaśambhupaddhati, vol. 3. Pondichéry: Institut Français, 1977.

Svacchanda-tantra with the commentary (Svacchandoddyota) of Rājānaka Kșemarāja. Madhusūdan Kaul Śāstrī (ed.). Srinagar: KSTS vol. 3, 1921. 


\section{Secondary Literature}

Aranya, Hariharananda, Yoga Philosophy of Patañjali: containing his yoga aphorisms with commentary of Vyāsa in Sanskrit, and annotations thereon with copious hints on the practice of yoga (Calcutta: University of Calcutta, 1977).

Birch, Jason, The Amanaska: king of all yogas: a critical edition and annotated translation with a monographic introduction, DPhil., University of Oxford, 2013.

Chakrabarti, Kisor Kumar, Classical Indian Philosophy of Mind: The Nyāya Dualist Tradition (Delhi: MLBD, 1999).

Chatterji, Jagdish Chandra, Kashmir Shaivism (Srinagar: Kashmir Series of Texts and Studies, 1914).

Cousins, Lance, 'Vitakka/Vitarka and Vicāra: The Stages of Samādhi in Buddhism and Yoga,' Indo-Iranian Journal, vol. 35, nos. 2 and 3, (1992), pp. 137-55.

Duerlinger, J., Indian Buddhist Theories of Persons. Vasubandhu's 'Refutation of the Theory of a Self' (London: Routledge, 2003).

Flood, Gavin, 'The Purification of the Body in Tantric Ritual Representation,' Indo-Iranian Journal, vol 45, 2002, pp. 25-43. 
Flood, Gavin, The Truth Within: A History of Inwardness in Christianity, Hinduism, and Buddhism (Oxford: Oxford University Press, 2013).

Flood, Gavin, 'Implicit Anthropologies in Pre-Philosophical Śaivism,' Journal of Indian Philosophy, vol. 48 (4), 2020, pp. 675-701.

Franco, Eli (ed.) in collaboration with Dagmar Eigner, Yogic Perception, Meditation, and Altered States of Consciousness (Vienna: Verlag der Österreichischen Akademie der Wissenschaften, 2009).

Frazier, Jessica. Hindu Worldviews: Theories of Self, Ritual and Reality. London: Bloomsbury, 2017.

Garfield Jay, Engaging Buddhism: Why it Matters to Philosophy (Oxford: Oxford University Press, 2015).

Ganeri, J., Philosophy in Classical India (London: Routledge, 2001).

Gethin, R.M.L., The Buddhist Path to Awakening (Oxford: One World, 2001 [1992]).

Goodall, Dominic, 'How the Tattvas of Tantric Saivism Came to Be 36: the Evidence of the Niśvāsatattvasaṃhitā,' in Dominic Goodall and Harunaga Isaacson (eds.), Tantric Studies: Fruits of a Franco-German Project on Early Tantra (Pondichéry: Institut Frañcais, 2016), pp. $77-112$. 
Guenther, Herbert V., 'The Concept of Mind in Buddhist Tantrism,' Journal of Oriental Studies Hong Kong, vol. 3, July 1956, pp. 261-77.

Guenther, Herbert V., Philosophy and Psychology in the Abhidharma (Delhi: Motilal, 1974).

Isaacson, Harunaka, 'Initiation (abhișeka) in the Higher Buddhist Tantric Systems,' in Astrid Zotter and Christoff Zotter (eds.), Hindu and Buddhist Initiations in India and Nepal (Wiesbaden: Harrassowitz Verlag, 2010), pp. 261-79.

Jayatilleke, K.N., Early Buddhist Theory of Knowledge (London: George Allen and Unwin, 1963).

Larson, G.J. and Ram Shankar Bhattacharya (eds), Encyclopedia of Indian Philosophies vol IV, Sāṃkya, a Dualist Tradition in Indian Philosophy (Delhi: MLBD, 1987).

Mallinson, James, 'Hațayoga's Early History: From Vajrayāna Sexual Restraint to Universal Somatic Soteriology,' in Gavin Flood (ed.), The Oxford History of Hinduism: Hindu Practice (Oxford: Oxford University Press, 2020), pp. 177-97.

McDaniel, Kris, The Fragmentation of Being (Oxford: Oxford University Press, 2017).

Padoux, André, Rescherches sur la Symolique et l'Énergie de la Parole dans certains textes tantrique (Paris: de Boccard, 1963.

Parfit, Derek, Reasons and Persons (Oxford: Oxford University Press, 1984). 
Ratié, Isabelle. Le Soi et l'Autre: Identité, difference et altérité dand la philosophie de a Pratyabhijñā. Leiden: Brill, 2011.

Ricoeur, Paul, Oneself as Another, translated by Kathleen Blamey (Chicago: Chicago University Press,1992).

Sanderson, Alexis, 'Mandala and the Āgamic Identity in the Trika of Kashmir,' André Padoux (ed.), Mantras et Diagrammes Rituels dans l'Hindouisme (Paris: CNRS, 1986), pp. 169-207.

Sanderson, Alexis, 'Vajrayāna: Origin and Function,' in Buddhism Into the Year 2000. International Conference Proceedings (Bangkok and Los Angeles: Dhammakaya Foundation, 1995), pp. 89-102.

Sanderson, Alexis, 'Śaiva Literature,' Journal of Indological Studies, nos. 24 \& 25 (20122013), pp. 1-113.

Takasaki, Jikido, A Study of the Ratnagotravibhāga (Uttaratantra), Being a Treatise on the Tathāgatagarbha Theory of Mahāyāna Buddhism (Rome: Instiuto Italiano per il Medio ed Estremo Oriente, 1966).

Vasudeva, Somadeva, The Yoga of the Mālinīvijayottaratantra (Pondichéry: Institut Français, 2004).

Watson, Alex, The Self's Awareness of Itself: Bhatța Rämakanța's Arguments Against the Buddhist Doctrine of No-Self(Vienna: Institut für Südasien-, Tibet- und Buddhismuskunde der Universität Wien, 2006). 
Wernicke-Olesen, Bjarne and Silje Lyngar Einarsen. 'Übungswissen in Yoga, Tantra und Asketismus.' In Almut-Barbara Renger and Alexandra Stellmacher (eds.). Übungswissen in Religion und Philosophie: Produktion, Weitergabe, Wandel. Berlin: Lit Verlag, 2018, pp. 24157. 